\title{
Probabilistic Inference Hybrid IT Value Model Using Bayesian Network
}

\author{
I Gusti Bagus Baskara Nugraha, Imaniar Ramadhani, and Jaka Sembiring \\ School of Electrical Engineering and Informatics \\ Institut Teknologi Bandung \\ Bandung, Indonesia \\ baskara@stei.itb.ac.id, imaniar.ramadhani@gmail.com,jaka@stei.itb.ac.id
}

\begin{abstract}
In this study, we propose probabilistic inference model on a hybrid IT value model using Bayesian Network $(\mathrm{BN})$ that represents uncertain relationships between 13 variables of the model. Those variables are performance, market, innovation, IT support, core competence, capabilities, knowledge, human resources, IT development, IT resources, capital, labor, and IT spending. The relationships between variables in the model are determined using probabilistic approach, including the structure, nature, and direction of relationships. We derive a probabilistic graphical model and measure the relationships between variables. The results of this study shows that the probabilistic approach with Bayesian Network can show that capabilities and core competence are the most important variables to produce high performance output.
\end{abstract}

Keywords: hybrid IT value model, probabilistic inference, Bayesian Network.

\section{Introduction}

The use of information technology (IT) requires organization leaders to be involved in IT planning and decision making [1]. The shift in IT perspective, which was originally only used as a tool for business support, has evolved into a major factor in organization's processes and implementation. Management support also needs to be considered in analyzing business strategies. This is consistent with the statement that managers see that IT investment will improve efficiency, business competitiveness [2], company performance, and appropriate decision making based on uncertainty [3]. For example, companies can find out the possibility of applying new technology to the income they receive later.

IT value measures interactions between information IT resources and organizational performances. There are several different perspectives on IT value, such as, but not limited to, production efficiency, computation speed, information retrieval, expanding choice sets, and ubiquity [4]. Several other perspectives have also been surveyed by [5]. To measure IT benefits or impacts in organization, IT value models have been developed, such as indirect-effect model [6], serial and parallel configuration model [7], and hybrid configuration of IT value model [8][9]. In hybrid configuration model, serial and parallel configuration models are merged to form a new model that fits IT investments in an IT organization. [9] showed that the proposed hybrid configuration model produced insignificant and tolerable deviation so that this can be used to substitute previous serial or parallel configuration models.

There are several methods to understand relationships between variables in hybrid IT value model, including correlation, multiple regression analysis [5], and Partial Adjustment Valuation (PAV) [10]-[12]. In correlation method, variables' relationships are identified by positive or negative values. In multiple regression analysis, an unknown variable is predicted from known variables or predictors. In the PAV method, the relationship between variables can be explained by the influence between variables.

All of those methods are able to explain causalities between variables, i.e., the value of a variable is caused by other variables. However, those methods still cannot explain uncertainties that may take place on variables. Relationships between variables can be probabilistic depending on organization characteristics, environment, or other related events. The probabilistic

Received: February $21^{\text {th }}, 2019$. Accepted: October $25^{\text {th }}, 2020$

DOI: $10.15676 /$ ijeei.2020.12.4.5 
relationship between variables can be expressed in the form of probabilistic inference using Bayesian Network (BN). BN has been widely used in describing uncertainty on various systems. In addition, BN has advantages in integrating data based on empirical analysis and knowledge from expert experience.

Hence, this research will discuss uncertainties in understanding causalities between variables using probabilistic inference, particularly Bayesian Network. The method proposed in this paper will complement previous methods in understanding causalities between variables in hybrid IT value model by considering uncertainties.

\section{Related Work}

IT value is an important parameter in organization since the use of IT nowadays is closely related to the performance gain obtained by the organization that has put investments on it. It refers to the usefulness or benefit of using information technology [13]. IT value can be classified into 3 categories: 1) tangible value based on directly measured performance, such as revenue increase, 2) intangible value that cannot be measured directly, such as customer satisfaction, and 3) neutral value that brings change to the internal of organization [12].

To measure the value of IT, a model is required to represent the relationships between IT value variables to the performance of the organization. Basically 3 IT value models exist: serial, parallel, and hybrid model [9]. In serial model, all variables are interconnected serially where the input is IT resource, and the final output is the performance of the organization. All other variables take places between those two variables where a specific variable has direct effect to another variable. In parallel model, all variables have direct effect to the performance. Meanwhile, hybrid IT value model combines both serial and parallel model such that only specific variables will have direct effect to the performance, while the others have indirect effect so that they will serially connected. This hybrid model produced better results in representing the actual condition in an organization [5]. It has 4 main components: IT resources, capabilities, core competence, and performance. IT resources component is affected by capital, labor, and IT spending. Capabilities component is affected by knowledge, human resources, and IT development. Core competence component is affected by market, innovation, and IT support.

The hybrid model in [5] was then validated using meta-analysis approach by calculating correlations between variables so that the effect of a variable to performance. However, this method can only show the positive or negative correlation between variables without generating knowledge on causality (e.g., variable $\mathrm{X}$ is affected by variable $\mathrm{Y}$ ). It cannot show how much one variable affects the other. Hence, [12] proposed model validation using Partial Adjustment Valuation (PAV) method. The model comes with PAV equations and indicators for all variables so that causality can be drawn explicitly. PAV is used because it was considered to be the most accurate technique to calculate the effect of IT in organization performance. Lin et al. [10] used static PAV to measure IT performance. A dynamic PAV is used by [12] in its hybrid IT value model. Although causality could be explained using PAV, uncertainties in variables that may affect performance had not been discussed yet.

In this paper, we add uncertainty factor into consideration when evaluating the effect of a variable to the performance. Causal relationship with uncertainty can be modeled by using Bayesian Networks, a probabilistic graphical model [14] that has been widely used in many applications [15][16]. Bayesian Networks have ability to reason without complete information and by taking new information into account [17]. Variables are represented as nodes connected using directed acyclic graph. The arcs or edges between nodes represent causal dependency. Bayesian Network has parameters to determine state and probability of each variable so that knowledge of a node can be perceived [18]. Each node has uncertainty parameter indicated by a value of conditional probability between 0 and 1 . This conditional probability represents a likelihood an event occurs when another event also occurs. The structure of the network is represented by using a conditional probability table (CPT) whose values are all conditional probability value in every node. This paper shows how to build CPT based on actual data provided in [12] and to search for important variables that highly affect performance. 
There is no definite method to construct Bayesian Network [19]. The structure is drawn using directed acyclic graph and it can be built using Pearl's algorithm [20]. In this case, root node is assigned an unconditional probability table, while the CPT of other nodes depend on the states of their parent nodes.

Sensitivity analysis [21] is used to analyze Bayesian Network structure to identify the variables that affect the objective variable the most. In our case, the objective variable is performance. The sensitivity is calculated using mutual information equation from information theory.

\section{Identification of Bayesian Network Development}

\section{A. Identification of Random Variables}

Random variables are identified by determining the value limitation on variable values known as normalization. Normalization is a process to find out the limits of each data value and carried out based on the data used in previous research [10]. The variable is 3 -valued variable to reduce complexity [22].

\section{B. Identification of Bayesian Network Structure}

Identification of the structure of $\mathrm{BN}$ is generated from the sequence/dependency of the relationship by random variables that have been determined through the results of previous research [6]. The structure is defined as directed acyclic graph (DAG) to find out the relationship between random variables/nodes. A node has a relationship and dependency with other nodes.

\section{Identification of Conditional Probability Table}

After developing the structure of $\mathrm{BN}$, every possible conditional probability distribution at each node in the network is represented using a table known as conditional probability table (CPT). An initial estimation value is assigned into a CPT before calculation joint distribution. Furthermore, the variable in the root node will be calculated using a joint and conditional probability distribution of each node that matches the graphic structure.

\section{Defining Variables}

\section{Definition 1}

Assume that the sample space $\mathrm{S}$ is a discrete random variable consisting of sample points $\left\{X_{1}, \ldots, X_{k}\right\}$. V represents firm performance, $Z_{1}$ represents market, $Z_{2}$ represents innovation, $Z_{3}$ represents IT support, $Z_{4}$ represents core competence, $Y_{4}$ represents capabilities, $Y_{1}$ represents knowledge, $Y_{2}$ represents human resources, $Y_{3}$ represents IT development, $X_{4}$ represents IT resources, $X_{1}$ represents capital, $X_{2}$ represents labor, $X_{3}$ represents IT spending.

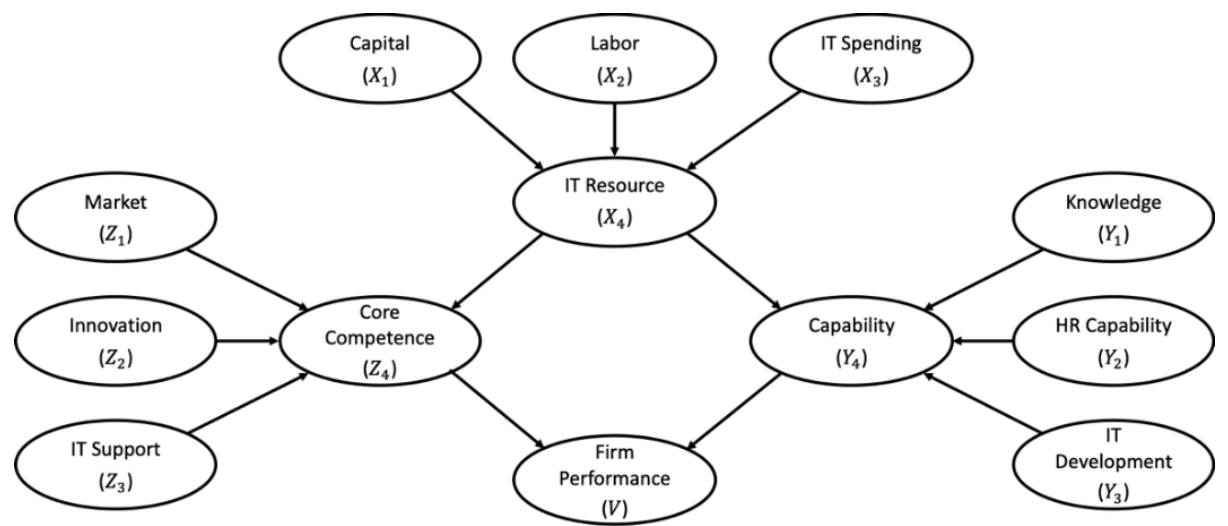

Figure 1. Graphical Structure of Variable Relationship using Bayesian Network 
Figure 1 depicts graphical representation of relationship between variables in Definition 1 . This graph is derived from hybrid configuration model proposed in [9]. It can be seen that in the relationship between IT resources $\left(X_{4}\right)$ and firm performance $(V)$ there are intermediate variables namely capability $\left(Y_{4}\right)$ and core competence $\left(Z_{4}\right)$. IT resources themselves are variables that are influenced by capital variables $\left(X_{1}\right)$, labor $\left(X_{2}\right)$, and IT spending $\left(X_{3}\right)$, while capability is a variable that is influenced by knowledge $\left(Y_{1}\right)$, HR capability $\left(Y_{2}\right)$, and IT development $\left(Y_{3}\right)$. On the other hand, core competence is a variable that is influenced by market variables $\left(Z_{1}\right)$, innovation $\left(Z_{2}\right)$, and IT support $\left(Z_{3}\right)$. Both capability and core competence variables will directly affect firm performance.

\section{Definition 2}

Assume $p_{i}$ represents the probability of the sample point $i$ then the probability distribution $P$ for the sample space $S$ fulfills the conditions:

a. All probability sample points must lie between 0 and 1, i.e. $0 \leq p_{i} \leq 1, i \in S$

b. Probability of all sample points in the sample space must sum to 1, i.e. $\sum_{i \in S} p_{i}=1$

c. Disjoint if $X_{1}, X_{2} \in S$ and $X_{1} \cap X_{2}=\emptyset$, then $P\left(X_{1} \cup X_{2}\right)=P\left(X_{1}\right)+P\left(X_{2}\right)$, and

d. Joint if $P(\varnothing)=0$, then $P\left(X_{1} \cup X_{2}\right)=P\left(X_{1}\right)+P\left(X_{2}\right)-P\left(X_{1} \cap X_{2}\right)$.

\section{Definition 3}

If random variable $\left\{X_{1}, \ldots, X_{k}\right\}$ that is known to fulfill the assumption of conditional independence, mutually exclusive, and Markov property based on the chain rule $\left\{X_{1}, \ldots, X_{k}\right\}$, the relationship of each variable can be written as

$$
\mathrm{P}\left(X_{1}, \ldots, X_{k}\right)=P\left(X_{1}\right) P\left(X_{2} \mid X_{1}\right) \ldots P\left(X_{k} \mid X_{1}, \ldots, X_{k-1}\right)
$$

\section{Definition 4}

Two random variables are independent of each other if the occurrence of an event is not affected by the occurrence of another event. It can also be said that the probability of $X_{1}$ does not affect the occurrence of $X_{2}$ and satisfies

$$
P\left(X_{1} \mid X_{2}\right)=P\left(X_{1}\right) \text {. }
$$

Based on basic rules of probability,

$$
P\left(X_{1}, X_{2}\right)=P\left(X_{1}\right) P\left(X_{2}\right)
$$

\section{Definition 5}

Assumed that successively $X_{1}, X_{2}, X_{3} \in X_{4}, Y_{1}, Y_{2}, Y_{3} \in Y_{4}, Z_{1}, Z_{2}, Z_{3} \in Z_{4}$ and $Y_{4}, Z_{4} \in V$. $X_{4}, Y_{4}, Z_{4}, V$ are descendants of $\left\{X_{1}, X_{2}, X_{3}\right\},\left\{Y_{1}, Y_{2}, Y_{3}\right\},\left\{Z_{1}, Z_{2}, Z_{3}\right\},\left\{Y_{4}, Z_{4}\right\}$, respectively, which fulfills independent conditional relations to $X_{4}, Y_{4}, Z_{4}, V$.

\section{Definition 6}

The basis of a conditional probability table (CPT) representation is a table from the calculation of each connected node by determining joint probability distribution $\mathrm{P}$, which satisfies Definition 1 and Definition 4. Furthermore, random variables $X_{1}, X_{2}, X_{3}, Y_{1}, Y_{2}, Y_{3}, Z_{1}, Z_{2}, Z_{3}, X_{4}, Y_{4}, Z_{4}, V$ are calculated by multiplying each related variable.

\section{Definition 7}

The probability value of random variable is determined by using marginal distribution denoted by $P(x)=\sum_{y} P(x, y)$.

\section{Definition 8}

$X_{1}$ is conditionally independent of $X_{2}$ given $X_{3}$ in a distribution $\mathrm{P}$ if $\mathrm{P}$ satisfies $\left(X_{1}=x_{1} \perp X_{2}=\right.$ $\left.x_{2} \mid X_{3}=x_{3}\right) . X_{3}$ is referred to as an observed variable defined by

$$
\mathrm{P}\left(X_{1} \perp X_{2} \mid X_{3}\right)=P\left(X_{1} \mid X_{3}\right)
$$




\section{Proposition}

The following 3 propositions represent the probabilistic inference of hybrid IT value models using BN. Proposition 1 is the probability distribution of the BN structure from the IT value validation model, Proposition 2 is a CPT calculation model from the IT value validation model, and Proposition 3 is a $\mathrm{BN}$ observation model that is used to calculate the variable probability values from the IT value model.

\section{Proposition 1}

The BN structure in the model explicitly meets conditional independence conditions. If $\mathrm{P}$ is a distribution of $\mathrm{X}$, an independent structure $I(P)$ can be written as

$$
I(P) \equiv X_{i} \perp\left\{X_{1}, \ldots, X_{i-1} \mid \operatorname{Parent}\left(X_{i}\right)\right\}
$$

\section{Proof 1}

The condition that applies conditional independence, as defined in Definition 8, as well as the dseparation conditions of the BN structure, may both be described in equation (6). $X_{1}, \ldots, X_{i-1}$ can also be referred to as Non Descendant from $X_{i}$.

$$
\begin{gathered}
\mathrm{I}(\mathrm{G})=\left\{\left(V \perp Y_{1}, Y_{2}, Y_{3}, X_{4} \mid Y_{4}\right),\left(V \perp Z_{1}, Z_{2}, Z_{3}, X_{4} \mid Z_{4}\right),\left(Y_{4} \perp X_{1}, X_{2}, X_{3} \mid X_{4}\right),\right. \\
\left(Z_{4} \perp X_{1}, X_{2}, X_{3} \mid X_{4}\right),\left(Z_{4} \perp Y_{1}, Y_{2}, Y_{3}, X_{4} \mid Y_{4}\right),\left(Y_{4} \perp Z_{4} \mid X_{4}\right), \\
\left(\mathrm{V} \perp Y_{4} \mid Z_{4}\right),\left(\mathrm{V} \perp X_{4} \mid Y_{4}, Z_{4}\right),\left(Z_{4} \perp X_{4} \mid Y_{4}\right),\left(X_{1} \perp X_{2}, X_{3} \mid \varnothing\right), \\
\left(X_{2} \perp X_{1}, X_{3} \mid \varnothing\right),\left(X_{3} \perp X_{1}, X_{2} \mid \varnothing\right),\left(Z_{1} \perp X_{4}, Y_{4} \mid \emptyset\right), \\
\left(Z_{2} \perp X_{4}, Y_{4} \mid \varnothing\right),\left(Z_{3} \perp X_{4}, Y_{4} \mid \varnothing\right),\left(X_{4} \perp Z_{1}, Z_{2}, Z_{3} \mid \emptyset\right), \\
\left(X_{4} \perp Y_{1}, Y_{2}, Y_{3} \mid \varnothing\right),\left(Y_{1} \perp X_{4}, Z_{4} \mid \varnothing\right),\left(Y_{2} \perp X_{4}, Z_{4} \mid \varnothing\right), \\
\left(Y_{3} \perp X_{4}, Z_{4} \mid \varnothing\right),\left(Y_{4} \perp Z_{4} \mid \varnothing\right),\left(Z_{4} \perp Y_{4} \mid \varnothing\right),\left(X_{4} \perp Y_{4} \mid \varnothing\right), \\
\left.\left(Y_{4} \perp Z_{1}, Z_{2}, Z_{3}, Z_{4}, V \mid X_{4}\right),\left(Z_{4} \perp Y_{1}, Y_{2}, Y_{3}, Y_{4}, V \mid X_{4}\right)\right\}
\end{gathered}
$$

or

$$
I(G) \equiv X_{i} \perp\left\{X_{1}, \ldots, X_{i-1} \mid \text { Parent }\left(X_{i}\right)\right\}
$$

After it was proven that the BN structure fulfilled conditional independent conditions, then the BN structure was developed from probabilistic inference presented in Proposition 2.

\section{Proposition 2}

Using Definition 6 and Proposition 1, the BN structure is constructed by representing all components of the BN into a CPT. The BN structure of the IT value validation method is described in equation (8) as

$$
P(\mathrm{~S})=\prod_{i=1}^{n} P\left(S_{i} \mid \operatorname{Pa}\left(S_{i}\right)\right)
$$

where $S_{i} \mid \mathrm{Pa}\left(S_{i}\right)$ is conditional probability distribution, is the index of random variable $S=$ $\left\{X_{1}, X_{2}, X_{3}, X_{4}, Y_{1}, Y_{2}, Y_{3}, Y_{4}, Z_{1}, Z_{2}, Z_{3}, Z_{4}, V\right\}$, and $P a\left(S_{i}\right)$ is the parent of $S_{i}$.

\section{Proof 2}

The BN structure of the hybrid IT value probabilistic inference model is calculated based on previous research by [5]. So, using Definition 4, the random variable S that meets Proposition 1 can be explained by equations (9) and (10).

$$
\begin{aligned}
P(S)= & P\left(X_{1}\right) \times P\left(X_{2}\right) \times P\left(X_{3}\right) \times P\left(X_{4} \mid X_{1}, X_{2}, X_{3}\right) \times \\
& P\left(Y_{1}\right) \times P\left(Y_{2}\right) \times P\left(Y_{3}\right) \times P\left(Y_{4} \mid Y_{1}, Y_{2}, Y_{3}, X_{4}\right) \times \\
& P\left(Z_{1}\right) \times P\left(Z_{2}\right) \times P\left(Z_{3}\right) \times P\left(Z_{4} \mid Z_{1}, Z_{2}, Z_{3}, X_{4}\right) \times \\
& P\left(V \mid Z_{4}, Y_{4}\right)
\end{aligned}
$$

or

$$
P(\mathrm{~S})=\prod_{i=1}^{n} P\left(S_{i} \mid P a\left(S_{i}\right)\right)
$$


After the BN structure in the probabilistic inference of the hybrid IT value model (Proposition 2) is obtained, the model will be calculated based on the probability distribution value of each $\mathrm{BN}$ variable. Model calculations are presented in Proposition 3.

\section{Proposition 3}

By using Definitions 1, 3, 4, 5, and 6, the probability distribution values of each node can be expressed in CPT, which is calculated by multiplying each of the corresponding S. In general, joint probability distribution $\mathrm{P}(\mathrm{S})$ can be written in the form of equation $(11) . P(S)=(X, Y)$, $\mathrm{X}, \mathrm{Y}$ is a representation of random variables that are interconnected $Y \rightarrow X$.

$$
P(X, Y)=P(X \mid Y) P(Y)
$$

\section{Proof 3}

By using Definition 6, if a given random variable $n \times m$, where $n$ is a row and $m$ is a column, meets the joint probability $P\left(X_{1}, X_{2}\right)=P\left(X_{1} \mid X_{2}\right) P\left(X_{2}\right)$, then CPT is produced, which is equivalent to equation (11).

\section{Proposition 4}

Based on the calculated CPT, the probability value $P(V)$ can be calculated using Definition 7 by adding up the values in rows or columns in the table stated in equation (12).

$$
P\left(V_{j}\right)=\sum_{V_{i} \forall i \neq j} P\left(\cap_{i} V_{i} \forall_{i}\right)
$$

\section{Proof 4}

By using Definition 7, the probability value of $\mathrm{P}(\mathrm{V})$ is calculated from the sum of the columns or rows of the joint distribution that meet conditional probability conditions and disjoint rules as in

Table 1 .

\begin{tabular}{|c|c|c|c|c|c|c|c|}
\hline & \multicolumn{3}{|c|}{$Y_{4}$} & \multicolumn{3}{|c|}{$Z_{4}$} & \multirow{2}{*}{$P(V)$} \\
\hline & High & Medium & Low & High & Medium & Low & \\
\hline $\begin{array}{l}V \\
=H i g h\end{array}$ & $\begin{array}{l}P\left(V \mid Y_{4}\right. \\
=H i g h)\end{array}$ & $\begin{array}{l}P\left(V \mid Y_{4}\right. \\
=\text { Medium })\end{array}$ & $\begin{array}{l}P\left(V \mid Y_{4}\right. \\
=\text { Low })\end{array}$ & $\begin{array}{l}P\left(V \mid Z_{4}\right. \\
=H i g h)\end{array}$ & $\begin{array}{l}P\left(V \mid Z_{4}\right. \\
=\text { Medium })\end{array}$ & $\begin{array}{l}P\left(V \mid Z_{4}\right. \\
=L o w)\end{array}$ & $\begin{array}{l}P(V \\
=H i g h)\end{array}$ \\
\hline $\begin{array}{l}V \\
=\text { Medium }\end{array}$ & $\begin{array}{l}P\left(V \mid Y_{4}\right. \\
=H i g h)\end{array}$ & $\begin{array}{l}P\left(V \mid Y_{4}\right. \\
=\text { Medium })\end{array}$ & $\begin{array}{l}P\left(V \mid Y_{4}\right. \\
=L o w)\end{array}$ & $\begin{array}{l}P\left(V \mid Z_{4}\right. \\
=H i g h)\end{array}$ & $\begin{array}{l}P\left(V \mid Z_{4}\right. \\
=\text { Medium })\end{array}$ & $\begin{array}{l}P\left(V \mid Z_{4}\right. \\
=\text { Low })\end{array}$ & $\begin{array}{l}P(V \\
=\text { Medium })\end{array}$ \\
\hline$V=L o w$ & $\begin{array}{l}P\left(V \mid Y_{4}\right. \\
=H i g h)\end{array}$ & $\begin{array}{l}P\left(V \mid Y_{4}\right. \\
=\text { Medium })\end{array}$ & $\begin{array}{l}P\left(V \mid Y_{4}\right. \\
=\text { Low })\end{array}$ & $\begin{array}{l}P\left(V \mid Z_{4}\right. \\
=H i g h)\end{array}$ & $\begin{array}{l}P\left(V \mid Z_{4}\right. \\
=\text { Medium })\end{array}$ & $\begin{array}{l}P\left(V \mid Z_{4}\right. \\
=\text { Low })\end{array}$ & $\begin{array}{l}P(V \\
=L o w)\end{array}$ \\
\hline
\end{tabular}

Table 1. CPT from $\mathrm{P}(\mathrm{V})$ values

\section{Propagation on Bayesian Network (BN)}

Propagation on BN exists in two ways, namely downward propagation or belief updating and upward propagation or bottom-up. Downward propagation of evidence at $\mathrm{BN}$ is calculated by a joint probability calculation, which is summed up by one (Definition 1). Therefore, the low, medium, and high levels found in each variable of capital, labor, IT spending and IT resources can be calculated in a row using equations (22). Similarly, upward propagation of evidence can be calculated in a row as in equation (23), which is based on Bayes' Rule theorem.

Assume that

$$
\begin{aligned}
& A=\left(X_{1}=\text { low }, X_{2}=\text { low }, X_{3}=\text { low }\right) \\
& B=\left(X_{1}=\text { low }, X_{2}=\text { low }, X_{3}=\text { medium }\right) \\
& C=\left(X_{1}=\text { low }, X_{2}=\text { low }, X_{3}=\text { high }\right) \\
& D=\left(X_{1}=\text { low }, X_{2}=\text { medium }, X_{3}=\text { low }\right) \\
& E=\left(X_{1}=\text { low }, X_{2}=\text { medium }, X_{3}=\text { medium }\right) \\
& F=\left(X_{1}=\text { low }, X_{2}=\text { medium }, X_{3}=\text { high }\right)
\end{aligned}
$$




$$
\begin{aligned}
& G=X_{1}=\text { low }, X_{2}=\text { high }, X_{3}=\text { low } \\
& H=\left(X_{1}=\text { low }, X_{2}=\text { high }, X_{3}=\text { medium }\right) \\
& I=\left(X_{1}=\text { low }, X_{2}=\text { high } X_{3}=\text { high }\right)
\end{aligned}
$$

the equation of downward propagation can be written as

$$
\begin{aligned}
P\left(X_{4}=\text { low }\right)= & P\left(X_{4}=\text { low } \mid A\right) P(A)+P\left(X_{4}=\text { low } \mid B\right) P(B)+P\left(X_{4}=\text { low } \mid C\right) P(C) \\
& +P\left(X_{4}=\text { low } \mid D\right) P(D)+P\left(X_{4}=\text { low } \mid E\right) P(E)+P\left(X_{4}=\text { low } \mid F\right) P(F) \\
& +P\left(X_{4}=\text { low } \mid G\right) P(G)+P\left(X_{4}=\text { low } \mid H\right) P(H)+P\left(X_{4}=\right.\text { low }
\end{aligned}
$$

and the equation of upward propagation can be written as

$$
P\left(A \mid X_{4}=\text { low }\right)=\frac{P\left(X_{4}=\operatorname{low} \mid A\right) P\left(X_{4}=\operatorname{low} \mid A\right)}{P\left(X_{4}=\text { low }\right)}
$$

As the size of the BN increases, propagation of information renewal in the network can be limited through conditional independence. The conditional independence condition applies if each variable and descent variable is separated or blocked by another variable given evidence of another variable (d-separation). Figure 2(a) describes a serial relationship, which states that $X_{1}$ affects $X_{3}$ and $X_{3}$ affects $X_{2}$. It is clear that the evidence $X_{1}$ will affect the degree of certainty in $X_{2}$. In other word, the evidence on $X_{1}$ affects the degree of certainty in $X_{2}$ through $X_{3}$. If $X_{3}$ is given an evidence, the relationship between $X_{1}$ and $X_{2}$ are blocked and the two variables apply conditional independence. Figure 2(b) describes the divergent relationship, which states that the influence can flow to $X_{1}$ and $X_{2}$ if the evidence in $X_{3}$ does not exist. Conversely, if the evidence is known in $X_{3}$, the relationship between all children of $X_{3}$ will be blocked, so that the change in the degree of certainty in $X_{1}$ will not affect the degree of certainty in $X_{2}$. Figure 2(c) describes a convergent relationship, which states that if there is no known evidence in $X_{3}$, then the values of the parent nodes, $X_{1}$ and $X_{2}$, will not affect the probability of the other nodes. Conversely, if the value of $X_{3}$ is known, the parent nodes, $X_{1}$ and $X_{2}$, will affect the other nodes. Therefore, two nodes $X_{1}$ and $X_{2}$ are said to be conditionally independent if there exist nodes blocked by $X_{3}$. If two nodes are conditionally independence, then the network does not need to calculate conditional probabilities for each node.

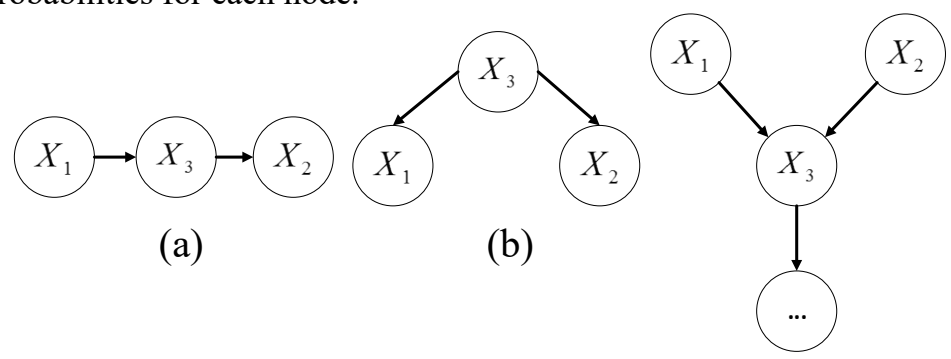

(c)

Figure 2. Types of Bayesian Network Relationship: (a) Serial, (b) Divergent, and (c) Convergent

\section{Implementation}

\section{A. Making Connected Graphs}

The IT value model with indirect impacts is chosen as a reference because it can better illustrate the influence of IT on performance. This model is formed based on four main variables: IT resources $\left(X_{4}\right)$, capabilities $\left(Y_{4}\right)$, core competencies $\left(Z_{4}\right)$, and performance $(V)()$. IT resources $\left(X_{4}\right)$ are influenced by capital $\left(X_{1}\right)$, employee salary $\left(X_{2}\right)$, and IT spending $\left(X_{3}\right)$. Capabilities $\left(Y_{4}\right)$ are influenced by knowledge capability $\left(Y_{1}\right)$, human resource capability $\left(Y_{2}\right)$, and IT development capability $\left(Y_{3}\right)$. Meanwhile, core competencies $\left(Z_{4}\right)$ are influenced by 
market competencies $\left(Z_{1}\right)$, innovation competencies $\left(Z_{2}\right)$, and IT support competencies $\left(Z_{3}\right)$. Performance $(V)$ describes income generated per year.

\section{B. Finding a Prior Value}

Prior values are obtained by calculating the probability of data distribution. This research uses the same data as in [12]. The data is proven to be normally distributed by using an analysis of skewness and kurtosis values. Furthermore, the data is normalized using interval discretization algorithm that is divided into three categories (low, medium, high) for simplicity and by calculating its data probability values based on existing data ranges as shown in Table 2.

Table 2. Normalization Data

\begin{tabular}{|l|c|c|c|c|c|c|c|c|c|c|}
\hline Categories & $\mathrm{X} 1$ & $\mathrm{X} 2$ & $\mathrm{X} 3$ & $\mathrm{Y} 1$ & $\mathrm{Y} 2$ & $\mathrm{Y} 3$ & $\mathrm{Z} 1$ & $\mathrm{Z} 2$ & $\mathrm{Z} 3$ & $\mathrm{~V}$ \\
\hline Low & 0.4 & 0.6 & 0.5 & 0.4 & 0.4 & 0.3 & 0.4 & 0.4 & 0.5 & 0.4 \\
\hline Medium & 0.4 & 0.2 & 0.3 & 0.3 & 0.2 & 0.3 & 0.3 & 0.2 & 0.2 & 0.2 \\
\hline High & 0.2 & 0.2 & 0.2 & 0.3 & 0.4 & 0.4 & 0.4 & 0.4 & 0.3 & 0.4 \\
\hline
\end{tabular}

The prior values of $X_{4}, Y_{4}$, and $Z_{4}$ are determined by calculating the latent score obtained through SmartPLS software (see Table 3). According to [12], this is a way to determine discoverer knowledge programs that are used to estimate previous conditional probabilities. First, each variable is discredited into three categories (called low, medium, high). The method of division into three categories in order to identify variables has been chosen to prevent complexity in assessing results. Conditional probability values are estimated based on frequency. This means that the data range is divided into three equal categories, and the frequency of each section in the data is calculated.

\section{Determine Joint Values}

Joint value is obtained from all possible combinations of the calculation of prior values on each node so that the probability value for each variable is generated. After the structure is learned, calculating the probability value can be used to train the network further. If more data is available in conditional probability conditions, the network node will change. shows the value of a joint based on the definition of the $X_{4}$ structure that is affected by $X_{1}, X_{2}, X_{3}$. shows the value of joints based on the definition of structure $Y_{4}$ which is influenced by $Y_{1}, Y_{1}, Y_{3}, X_{4}$. And, shows the value of joints based on the definition of the $Z_{4}$ structure which is influenced by $Z_{1}, Z_{2}, Z_{3}, X_{4}$. Whereas, shows the value of joints based on the definition of structure $\mathrm{V}$ which is affected by $Y_{4}, Z_{4}$.

Table 3. Calculation of Latent Score

\begin{tabular}{|c|c|c|}
\hline \multicolumn{3}{|c|}{ Standardized Latent variables } \\
\hline$X_{4}$ & $Y_{4}$ & $Z_{4}$ \\
\hline-1.257419747 & -1.530284178 & -1.537999868 \\
\hline-1.061254248 & -1.436732782 & -1.439161844 \\
\hline-0.821231555 & -0.725510536 & -0.737239837 \\
\hline-0.624124072 & -0.503412092 & -0.489589828 \\
\hline-0.478902102 & -0.118598945 & -0.112500230 \\
\hline-0.066141436 & 0.149709501 & 0.153288738 \\
\hline
\end{tabular}




\begin{tabular}{|c|c|c|}
\hline \multicolumn{3}{|c|}{ Standardized Latent variables } \\
\hline$X_{4}$ & $Y_{4}$ & $Z_{4}$ \\
\hline 0.453926719 & 0.528991321 & 0.544599274 \\
\hline 0.626708338 & 0.972056818 & 0.977339186 \\
\hline 1.310293189 & 1.28104394 & 1.275488052 \\
\hline 1.918144915 & 1.382736953 & 1.365776356 \\
\hline
\end{tabular}

Table 4. Join Values for $\mathrm{X}_{4}$

\begin{tabular}{|c|c|c|c|c|}
\hline Categories & $\boldsymbol{X}_{\mathbf{1}}$ & $\boldsymbol{X}_{\mathbf{2}}$ & $\boldsymbol{X}_{\mathbf{3}}$ & $\boldsymbol{X}_{\mathbf{4}}$ \\
\hline Low & 0.4 & 0.6 & 0.5 & 0.5 \\
\hline Medium & 0.4 & 0.2 & 0.3 & 0.3 \\
\hline High & 0.2 & 0.2 & 0.2 & 0.2 \\
\hline
\end{tabular}

Table 5. Join Values for $\mathrm{Y}_{4}$

\begin{tabular}{|c|c|c|c|c|c|}
\hline Categories & $\boldsymbol{Y}_{\mathbf{1}}$ & $\boldsymbol{Y}_{\mathbf{2}}$ & $\boldsymbol{Y}_{\mathbf{3}}$ & $\boldsymbol{X}_{\mathbf{4}}$ & $\boldsymbol{Y}_{\mathbf{4}}$ \\
\hline Low & 0.4 & 0.4 & 0.3 & 0.5 & 0.3 \\
\hline Medium & 0.3 & 0.2 & 0.3 & 0.3 & 0.3 \\
\hline High & 0.3 & 0.4 & 0.4 & 0.2 & 0.4 \\
\hline
\end{tabular}

Table 6. Join Values for $\mathrm{Z}_{4}$

\begin{tabular}{|c|c|c|c|c|c|}
\hline \multirow{2}{*}{ Categories } & $\mathrm{Z}_{1}$ & $\mathrm{Z}_{2}$ & $\mathrm{Z}_{3}$ & $\mathrm{X}_{4}$ & $\mathrm{Z}_{4}$ \\
& & & & & \\
\hline Low & 0.4 & 0.4 & 0.5 & 0.5 & 0.3 \\
\hline Medium & 0.3 & 0.2 & 0.2 & 0.3 & 0.3 \\
\hline High & 0.4 & 0.4 & 0.3 & 0.2 & 0.4 \\
\hline
\end{tabular}

Table 7. Join Values for $\mathrm{V}$

\begin{tabular}{|c|c|c|c|}
\hline Categories & Y4 & Z4 & V \\
\hline Low & 0.3 & 0.3 & 0.4 \\
\hline Medium & 0.3 & 0.3 & 0.2 \\
\hline High & 0.4 & 0.4 & 0.4 \\
\hline
\end{tabular}

\section{Evaluation}

\section{A. Model Research Analysis}

In this section, each variable will be analyzed using $\mathrm{BN}$. BN model has 13 nodes and 13 lines of connectivity. Posterior probabilities are simulated using Netica software [23] based on different scenarios and entered as evidence into the $\mathrm{BN}$. In this research, this scenario was 
prepared to examine the effect of changes in each variable if given evidence on other variables. Table 8 and 9 show posterior probability distribution using various scenarios.

Table 8 can be interpreted as follows. The first row of base case column of the table shows that without evidence the firm performance will be relatively low $(36.5 \%)$. Furthermore, if the model is given evidence with high firm performance values, then the opportunity value of core competence and capability will increase to $55.4 \%$ and $56.2 \%$. If an enhancement is made in the capital, labor, and IT spending or in other words given high value evidence on all three variables, then the firm performance opportunity value will increase from $34.1 \%$ in base case scenario to $37 \%$.

Analysis is also performed to evaluate the best path from IT resources to firm performance (see Table 9). Scenarios are given by providing evidence with a high value on the IT resources node and core competence node. The result is a high probability value on firm performance, resulting in an increase from $34.1 \%$ to $58.5 \%$. Whereas, if given a scenario with providing evidence with high values on IT resources and capabilities nodes, the high opportunity value of the firm performance will increase from $34.1 \%$ to $59.6 \%$. Even though the results of both are only differ about $1 \%$, probability value of firm performance results will get a better value if IT resources are passed through capabilities.

Analysis on child nodes that represent IT resources, capabilities, and core competencies are evaluated for their influence on the value of opportunities in firm performance. The first scenario is by providing evidence with high value on capital, labor, and IT spending so that the resulting high opportunity value on firm performance is $34.1 \%$ to $37 \%$. The second scenario is given evidence of high value in knowledge, HR capability, and IT development. The result in this scenario is the high opportunity value at a firm performance of $34.1 \%$ to $46.2 \%$. The third scenario is carried out by providing evidence of high value in the market, innovation, and IT support so that the resulting high opportunity value on firm performance is $34.1 \%$ to $39.2 \%$. Therefore, based on the first, second, and third scenarios, the test analysis can conclude that capabilities have a stronger influence compared to core competence and IT resources variables.

Table 8. Posterior Probability Distribution on Various Scenarios (1)

\begin{tabular}{|c|c|c|c|c|c|}
\hline No & Variables & Base case & $\begin{array}{l}\text { High Firm } \\
\text { Performance }\end{array}$ & $\begin{array}{c}\text { Low } \\
\text { Capability }\end{array}$ & $\begin{array}{c}\text { High Capital, } \\
\text { Labor, and IT } \\
\text { Spending }\end{array}$ \\
\hline 1 & $V$ & $\begin{array}{l}\operatorname{Low}(36.5 \%) \\
\operatorname{Med}(29.5 \%) \\
\operatorname{High}(34.1 \%)\end{array}$ & $\begin{array}{l}\text { Low }(0 \%) ; \\
\operatorname{Med}(0 \%) ; \\
\operatorname{High}(100 \%)\end{array}$ & $\begin{array}{l}\operatorname{Low}(55.4 \%) \\
\operatorname{Med}(21.9 \%) \\
\operatorname{High}(22.6 \%)\end{array}$ & $\begin{array}{l}\operatorname{Low}(34.7 \%) \\
\operatorname{Med}(28.3 \%) \\
\operatorname{High}(37 \%)\end{array}$ \\
\hline 2 & $Y_{4}$ & $\begin{array}{l}\operatorname{Low}(32.1 \%) ; \\
\operatorname{Med}(33.6 \%) ; \\
\operatorname{High}(34.1 \%)\end{array}$ & $\begin{array}{l}\text { Low }(21.5 \%) \\
\operatorname{Med}(22.3 \%) \\
\operatorname{High}(56.2 \%)\end{array}$ & $\begin{array}{l}\text { Low }(100 \%) \\
\operatorname{Med}(0 \%) ; \\
\text { High }(0 \%)\end{array}$ & $\begin{array}{l}\text { Low(31.4\%); } \\
\text { Med(31.4\%); } \\
\operatorname{High}(37.2 \%)\end{array}$ \\
\hline 3 & $Z_{4}$ & $\begin{array}{l}\text { Low }(33.3 \%) \\
\text { Med(33.4\%); } \\
\text { High(33.4\%) }\end{array}$ & $\begin{array}{l}\text { Low(22.5\%); } \\
\text { Med(22.1\%); } \\
\text { High(55.4\%) }\end{array}$ & $\begin{array}{l}\text { Low }(33.5 \%) \\
\text { Med(33.4\%); } \\
\text { High(33.1\%) }\end{array}$ & $\begin{array}{l}\text { Low }(30.6 \%) \\
\operatorname{Med}(30.6 \%) \\
\operatorname{High}(38.8 \%)\end{array}$ \\
\hline 4 & $X_{4}$ & $\begin{array}{l}\text { Low(45.9\%); } \\
\operatorname{Med}(31.5 \%) \\
\operatorname{High}(22.6 \%)\end{array}$ & $\begin{array}{l}\text { Low(24.5\%); } \\
\text { Med(33.1\%); } \\
\text { High(24.5\%) }\end{array}$ & $\begin{array}{l}\text { Low(49.6\%); } \\
\operatorname{Med}(28.5 \%) \\
\operatorname{High}(21.9 \%)\end{array}$ & $\begin{array}{l}\text { Low }(0 \%) ; \\
\text { Med(0\%); } \\
\text { High( }(100 \%)\end{array}$ \\
\hline 5 & $Y_{3}$ & $\begin{array}{l}\text { Low }(30 \%) ; \\
\text { Med(30\%); } \\
\text { High(40\%) }\end{array}$ & $\begin{array}{l}\operatorname{Low}(29 \%) \\
\operatorname{Med}(28.6 \%) \\
\operatorname{High}(42.4 \%)\end{array}$ & $\begin{array}{l}\operatorname{Low}(35.5 \%) \\
\operatorname{Med}(27.3 \%) \\
\operatorname{High}(37 \%)\end{array}$ & $\begin{array}{l}\text { Low(30\%); } \\
\text { Med(30\%); } \\
\text { High(40\%) }\end{array}$ \\
\hline 6 & $Y_{2}$ & $\begin{array}{l}\text { Low }(40 \%) ; \\
\text { Med(20\%); } \\
\text { High(40\%) }\end{array}$ & $\begin{array}{l}\text { Low }(29 \%) ; \\
\text { Med(28.6\%); } \\
\text { High }(42.4 \%)\end{array}$ & $\begin{array}{l}\text { Low }(43.6 \%) \\
\text { Med(19.2\%); } \\
\operatorname{High}(37.2 \%)\end{array}$ & $\begin{array}{l}\text { Low(40\%); } \\
\text { Med(20\%); } \\
\text { High(40\%) }\end{array}$ \\
\hline
\end{tabular}




\begin{tabular}{|c|c|c|c|c|c|}
\hline No & Variables & Base case & $\begin{array}{c}\text { High Firm } \\
\text { Performance }\end{array}$ & $\begin{array}{c}\text { Low } \\
\text { Capability }\end{array}$ & $\begin{array}{c}\text { High Capital, } \\
\text { Labor, and IT } \\
\text { Spending }\end{array}$ \\
\hline 7 & $Y_{1}$ & $\begin{array}{l}\text { Low(40\%); } \\
\text { Med(30\%); } \\
\text { High(30\%) }\end{array}$ & $\begin{array}{l}\text { Low(38.3\%); } \\
\text { Med(30.3\%); } \\
\text { High(31.5\%) }\end{array}$ & $\begin{array}{l}\operatorname{Low}(38.3 \%) \\
\operatorname{Med}(30.3 \%) \\
\operatorname{High}(31.5 \%)\end{array}$ & $\begin{array}{l}\text { Low(40\%); } \\
\text { Med(30\%); } \\
\text { High(30\%) }\end{array}$ \\
\hline 8 & $Z_{3}$ & $\begin{array}{l}\text { Low(50\%); } \\
\text { Med(20\%); } \\
\text { High(30\%) }\end{array}$ & $\begin{array}{l}\text { Low(49.1\%); } \\
\text { Med(19.5\%); } \\
\text { High(31.5\%) }\end{array}$ & $\begin{array}{l}\text { Low }(50 \%) ; \\
\text { Med(20\%); } \\
\text { High(30\%) }\end{array}$ & $\begin{array}{l}\text { Low(50\%); } \\
\text { Med(20\%); } \\
\text { High(30\%) }\end{array}$ \\
\hline 9 & $Z_{1}$ & $\begin{array}{l}\text { Low(30\%); } \\
\text { Med(30\%); } \\
\text { High(40\%) }\end{array}$ & $\begin{array}{l}\text { Low }(41 \%) ; \\
\text { Med(29.9\%); } \\
\operatorname{High}(29.1 \%)\end{array}$ & $\begin{array}{l}\text { Low }(30 \%) ; \\
\text { Med(30\%); } \\
\text { High(40\%) }\end{array}$ & $\begin{array}{l}\text { Low }(30 \%) ; \\
\text { Med(30\%); } \\
\text { High(40\%) }\end{array}$ \\
\hline 10 & $Z_{2}$ & $\begin{array}{l}\text { Low(40\%); } \\
\text { Med(20\%); } \\
\text { High(40\%) }\end{array}$ & $\begin{array}{l}\text { Low(40.7\%); } \\
\text { Med(20.6\%); } \\
\text { High(40.7\%) }\end{array}$ & $\begin{array}{l}\text { Low }(40 \%) ; \\
\text { Med(20\%); } \\
\text { High( }(40 \%)\end{array}$ & $\begin{array}{l}\text { Low(40\%); } \\
\text { Med(20\%); } \\
\text { High(40\%) }\end{array}$ \\
\hline 11 & $X_{3}$ & $\begin{array}{l}\text { Low(50\%); } \\
\text { Med(30\%); } \\
\text { High(20\%) }\end{array}$ & $\begin{array}{l}\text { Low(48.6\%); } \\
\text { Med(30.9\%); } \\
\text { High(20.5\%) }\end{array}$ & $\begin{array}{l}\text { Low(51.6\%); } \\
\operatorname{Med}(28.8 \%) ; \\
\operatorname{High}(19.7 \%)\end{array}$ & $\begin{array}{l}\text { Low }(0 \%) ; \\
\operatorname{Med}(0 \%) ; \\
\operatorname{High}(100 \%)\end{array}$ \\
\hline 12 & $X_{2}$ & $\begin{array}{l}\text { Low(60\%); } \\
\text { Med(20\%); } \\
\text { High(20\%) }\end{array}$ & $\begin{array}{l}\text { Low(59.1\%); } \\
\text { Med(20.5\%); } \\
\text { High(20.4\%) }\end{array}$ & $\begin{array}{l}\text { Low(60.8\%); } \\
\text { Med(19.5\%); } \\
\text { High(19.7\%) }\end{array}$ & $\begin{array}{l}\text { Low }(0 \%) ; \\
\operatorname{Med}(0 \%) ; \\
\operatorname{High}(100 \%)\end{array}$ \\
\hline 13 & $X_{1}$ & $\begin{array}{l}\text { Low(40\%); } \\
\text { Med(40\%); } \\
\text { High(20\%) }\end{array}$ & $\begin{array}{l}\text { Low(39.6\%); } \\
\text { Med(39.9\%); } \\
\text { High(20.4\%) }\end{array}$ & $\begin{array}{l}\text { Low(40.5\%); } \\
\text { Med(39.8\%); } \\
\text { High(19.7\%) }\end{array}$ & $\begin{array}{l}\text { Low }(0 \%) ; \\
\operatorname{Med}(0 \%) ; \\
\operatorname{High}(100 \%)\end{array}$ \\
\hline
\end{tabular}

Table 9. Posterior Probability Distribution on Various Scenarios (2)

\begin{tabular}{|c|c|c|c|c|c|c|}
\hline No & $\begin{array}{l}\text { Varia } \\
\text {-bles }\end{array}$ & $\begin{array}{c}\text { High IT } \\
\text { Resources and } \\
\text { Core } \\
\text { Competence }\end{array}$ & $\begin{array}{c}\text { High IT } \\
\text { Resources and } \\
\text { Capability }\end{array}$ & $\begin{array}{c}\text { High } \\
\text { Capital, } \\
\text { Labor, and } \\
\text { IT Spending }\end{array}$ & $\begin{array}{c}\text { High } \\
\text { Knowledge, } \\
\text { HR Cap. and } \\
\text { IT Dev. }\end{array}$ & $\begin{array}{l}\text { High Market, } \\
\text { Innovation, } \\
\text { and IT Sup. }\end{array}$ \\
\hline 1 & $V$ & $\begin{array}{l}\operatorname{Low}(20.7 \%) \\
\operatorname{Med}(20.7 \%) \\
\operatorname{High}(58.5 \%)\end{array}$ & $\begin{array}{l}\operatorname{Low}(20.2 \%) \\
\operatorname{Med}(20.2 \%) \\
\operatorname{High}(59.6 \%)\end{array}$ & $\begin{array}{l}\operatorname{Low}(34.7 \%) \\
\operatorname{Med}(28.3 \%) \\
\operatorname{High}(37 \%)\end{array}$ & $\begin{array}{l}\operatorname{Low}(28.8 \%) \\
\operatorname{Med}(25 \%) ; \\
\operatorname{High}(46.2 \%)\end{array}$ & $\begin{array}{l}\operatorname{Low}(33.1 \%) \\
\operatorname{Med}(27.6 \%) \\
\operatorname{High}(39.2 \%)\end{array}$ \\
\hline 2 & $Y_{4}$ & $\begin{array}{l}\operatorname{Low}(31.4 \%) \\
\operatorname{Med}(31.4 \%) \\
\operatorname{High}(37.2 \%)\end{array}$ & $\begin{array}{l}\text { Low }(0 \%) ; \\
\operatorname{Med}(0 \%) ; \\
\operatorname{High}(100 \%)\end{array}$ & $\begin{array}{l}\operatorname{Low}(31.4 \%) \\
\operatorname{Med}(31.4 \%) \\
\operatorname{High}(37.2 \%)\end{array}$ & $\begin{array}{l}\text { Low }(15.6 \%) \\
\operatorname{Med}(15.1 \%) \\
\operatorname{High}(69.2 \%)\end{array}$ & $\begin{array}{l}\operatorname{Low}(31.4 \%) \\
\operatorname{Med}(31.4 \%) \\
\operatorname{High}(37.2 \%)\end{array}$ \\
\hline 3 & $Z_{4}$ & $\begin{array}{l}\operatorname{Low}(0 \%) ; \\
\operatorname{Med}(0 \%) ; \\
\operatorname{High}(100 \%)\end{array}$ & $\begin{array}{l}\operatorname{Low}(30.6 \%) \\
\operatorname{Med}(30.6 \%) \\
\operatorname{High}(38.8 \%)\end{array}$ & $\begin{array}{l}\operatorname{Low}(30.6 \%) \\
\operatorname{Med}(30.6 \%) \\
\operatorname{High}(38.8 \%)\end{array}$ & $\begin{array}{l}\text { Low(33.3\%); } \\
\text { Med(33.4\%); } \\
\text { High(33.4\%) }\end{array}$ & $\begin{array}{l}\text { Low }(48.1 \%) \\
\operatorname{Med}(25.9 \%) \\
\operatorname{High}(26 \%)\end{array}$ \\
\hline 4 & $X_{4}$ & $\begin{array}{l}\text { Low }(0 \%) ; \\
\operatorname{Med}(0 \%) ; \\
\operatorname{High}(100 \%)\end{array}$ & $\begin{array}{l}\text { Low }(0 \%) ; \\
\operatorname{Med}(0 \%) ; \\
\operatorname{High}(100 \%)\end{array}$ & $\begin{array}{l}\operatorname{Low}(45.9 \%) \\
\operatorname{Med}(31.5 \%) \\
\operatorname{High}(22.6 \%)\end{array}$ & $\begin{array}{l}\text { Low(45.9\%); } \\
\operatorname{Med}(31.5 \%) \\
\operatorname{High}(22.6 \%)\end{array}$ & $\begin{array}{l}\text { Low(45.9\%); } \\
\operatorname{Med}(31.5 \%) \\
\operatorname{High}(22.6 \%)\end{array}$ \\
\hline 5 & $Y_{3}$ & $\begin{array}{l}\text { Low(30\%); } \\
\text { Med(30\%); } \\
\text { High(40\%) }\end{array}$ & $\begin{array}{l}\operatorname{Low}(27.4 \%) \\
\operatorname{Med}(27.4 \%) \\
\operatorname{High}(45.1 \%)\end{array}$ & $\begin{array}{l}\text { Low(30\%); } \\
\text { Med(30\%); } \\
\text { High(40\%) }\end{array}$ & $\begin{array}{l}\text { Low }(0 \%) ; \\
\operatorname{Med}(0 \%) ; \\
\operatorname{High}(100 \%)\end{array}$ & $\begin{array}{l}\text { Low(30\%); } \\
\text { Med(30\%); } \\
\text { High(40\%) }\end{array}$ \\
\hline
\end{tabular}


I Gusti Bagus Baskara Nugraha, et al.

\begin{tabular}{|c|c|c|c|c|c|c|}
\hline No & $\begin{array}{l}\text { Varia } \\
\text {-bles }\end{array}$ & $\begin{array}{c}\text { High IT } \\
\text { Resources and } \\
\text { Core } \\
\text { Competence } \\
\end{array}$ & $\begin{array}{c}\text { High IT } \\
\text { Resources and } \\
\text { Capability }\end{array}$ & $\begin{array}{c}\text { High } \\
\text { Capital, } \\
\text { Labor, and } \\
\text { IT Spending }\end{array}$ & $\begin{array}{c}\text { High } \\
\text { Knowledge, } \\
\text { HR Cap. and } \\
\text { IT Dev. }\end{array}$ & $\begin{array}{l}\text { High Market, } \\
\text { Innovation, } \\
\text { and IT Sup. }\end{array}$ \\
\hline 6 & $Y_{2}$ & $\begin{array}{l}\text { Low }(40 \%) ; \\
\text { Med(20\%); } \\
\text { High( }(40 \%)\end{array}$ & $\begin{array}{l}\text { Low }(36.6 \%) \\
\text { Med(18.3\%); } \\
\operatorname{High}(45.1 \%)\end{array}$ & $\begin{array}{l}\text { Low }(40 \%) ; \\
\text { Med(20\%); } \\
\text { High( }(40 \%)\end{array}$ & $\begin{array}{l}\text { Low }(0 \%) ; \\
\operatorname{Med}(0 \%) ; \\
\operatorname{High}(100 \%)\end{array}$ & $\begin{array}{l}\text { Low }(40 \%) ; \\
\text { Med(20\%); } \\
\text { High(40\%) }\end{array}$ \\
\hline 7 & $Y_{1}$ & $\begin{array}{l}\text { Low(40\%); } \\
\text { Med(30\%); } \\
\text { High(30\%) }\end{array}$ & $\begin{array}{l}\operatorname{Low}(36.6 \%) \\
\operatorname{Med}(27.4 \%) \\
\operatorname{High}(36 \%)\end{array}$ & $\begin{array}{l}\text { Low(40\%); } \\
\text { Med(30\%); } \\
\text { High(30\%) }\end{array}$ & $\begin{array}{l}\text { Low }(0 \%) ; \\
\operatorname{Med}(0 \%) ; \\
\operatorname{High}(100 \%)\end{array}$ & $\begin{array}{l}\text { Low(40\%); } \\
\text { Med(30\%); } \\
\text { High(30\%) }\end{array}$ \\
\hline 8 & $Z_{3}$ & $\begin{array}{l}\text { Low }(43.9 \%) \\
\operatorname{Med}(17.5 \%) \\
\operatorname{High}(38.6 \%)\end{array}$ & $\begin{array}{l}\text { Low }(50 \%) ; \\
\text { Med(20\%); } \\
\text { High(30\%) }\end{array}$ & $\begin{array}{l}\text { Low(50\%); } \\
\text { Med(20\%); } \\
\text { High(30\%) }\end{array}$ & $\begin{array}{l}\text { Low }(50 \%) ; \\
\text { Med(20\%); } \\
\text { High(30\%) }\end{array}$ & $\begin{array}{l}\text { Low }(100 \%) \\
\text { Med }(0 \%) ; \\
\operatorname{High}(0 \%)\end{array}$ \\
\hline 9 & $Z_{1}$ & $\begin{array}{l}\operatorname{Low}(26.3 \%) \\
\operatorname{Med}(26.3 \%) \\
\operatorname{High}(47.4 \%)\end{array}$ & $\begin{array}{l}\text { Low(30\%); } \\
\text { Med(30\%); } \\
\text { High(40\%) }\end{array}$ & $\begin{array}{l}\text { Low(30\%); } \\
\text { Med(30\%); } \\
\text { High(40\%) }\end{array}$ & $\begin{array}{l}\text { Low(30\%); } \\
\text { Med(30\%); } \\
\text { High(40\%) }\end{array}$ & $\begin{array}{l}\text { Low }(100 \%) \\
\text { Med }(0 \%) ; \\
\operatorname{High}(0 \%)\end{array}$ \\
\hline 10 & $Z_{2}$ & $\begin{array}{l}\operatorname{Low}(35.1 \%) \\
\operatorname{Med}(21.6 \%) \\
\operatorname{High}(43.3 \%)\end{array}$ & $\begin{array}{l}\text { Low(40\%); } \\
\text { Med(20\%); } \\
\text { High(40\%) }\end{array}$ & $\begin{array}{l}\text { Low(40\%); } \\
\text { Med(20\%); } \\
\text { High(40\%) }\end{array}$ & $\begin{array}{l}\text { Low(40\%); } \\
\text { Med(20\%); } \\
\text { High(40\%) }\end{array}$ & $\begin{array}{l}\text { Low }(100 \%) \\
\text { Med }(0 \%) \\
\text { High }(0 \%)\end{array}$ \\
\hline 11 & $X_{3}$ & $\begin{array}{l}\text { Low }(38 \%) ; \\
\operatorname{Med}(29.8 \%) \\
\operatorname{High}(32.2 \%)\end{array}$ & $\begin{array}{l}\text { Low }(38 \%) ; \\
\operatorname{Med}(25.9 \%) \\
\operatorname{High}(42.4 \%)\end{array}$ & $\begin{array}{l}\text { Low }(0 \%) ; \\
\operatorname{Med}(0 \%) ; \\
\operatorname{High}(100 \%)\end{array}$ & $\begin{array}{l}\text { Low(50\%); } \\
\text { Med(30\%); } \\
\text { High(20\%) }\end{array}$ & $\begin{array}{l}\text { Low(50\%); } \\
\text { Med(30\%); } \\
\text { High(20\%) }\end{array}$ \\
\hline 12 & $X_{2}$ & $\begin{array}{l}\text { Low(42.4\%); } \\
\operatorname{Med}(25.9 \%) ; \\
\operatorname{High}(31.7 \%)\end{array}$ & $\begin{array}{l}\text { Low(42.4\%); } \\
\operatorname{Med}(25.9 \%) \\
\operatorname{High}(31.7 \%)\end{array}$ & $\begin{array}{l}\text { Low }(0 \%) ; \\
\operatorname{Med}(0 \%) ; \\
\operatorname{High}(100 \%)\end{array}$ & $\begin{array}{l}\text { Low(60\%); } \\
\text { Med(20\%); } \\
\text { High(20\%) }\end{array}$ & $\begin{array}{l}\text { Low(60\%); } \\
\text { Med(20\%); } \\
\text { High(20\%) }\end{array}$ \\
\hline 13 & $X_{1}$ & $\begin{array}{l}\text { Low }(31.7 \%) \\
\operatorname{Med}(27 \%) ; \\
\operatorname{High}(31.7 \%)\end{array}$ & $\begin{array}{l}\operatorname{Low}(31.7 \%) \\
\operatorname{Med}(27 \%) ; \\
\operatorname{High}(31.7 \%)\end{array}$ & $\begin{array}{l}\text { Low }(0 \%) ; \\
\operatorname{Med}(0 \%) ; \\
\operatorname{High}(100 \%)\end{array}$ & $\begin{array}{l}\text { Low(40\%); } \\
\text { Med(40\%); } \\
\text { High(20\%) }\end{array}$ & $\begin{array}{l}\text { Low(40\%); } \\
\text { Med(40\%); } \\
\text { High(20\%) }\end{array}$ \\
\hline
\end{tabular}

\section{B. Sensitivity Analysis}

Sensitivity analysis is performed to find out the factors that most influenced the decision. Sensitivity analysis is performed using Netica software. Sensitivity analysis that will be carried out in this research is sensitivity to findings. The analysis of sensitivity to findings is used to measure the effect of one variable (X) on other variables (Y) using equation (14).

$$
I(X, Y)=\sum_{Y} \sum_{X} P(X, Y) \log _{2}\left(\frac{P(Y, X)}{P(Y) P(X)}\right)
$$

The result of sensitivity to the findings is the value of mutual information. Mutual information is about the amount of information a variable holds about another variable. In other words, it is an entropy reduction [24]. Based on the BN model, the biggest entropy reduction value lies in node capabilities and core competence, in addition to the firm performance nodes. Table is the result of the sensitivity analysis on the firm performance node based on . The highest entropy reduction value lies in the node capability of 0.1134 and the core competence is 0.1133 . This value indicates that the nodes that are influential or sensitive in determining the opportunities of firm performance are capabilities and core competence. These are part of the resources resulting from expertise and competence and the ability to control exploiting resources in implementing strategies. In addition to these two nodes, other nodes do not have a significant effect on the firm performance node. 
Table 10. Sensitivity Analysis Table of Firm Performance Belief in Other Nodes

\begin{tabular}{|l|l|l|}
\hline Node & Entropy reduction & Percentages \\
\hline Firm Performance & 1.57939 & 100 \\
\hline Capability & 0.11349 & 7.19 \\
\hline Core Competence & 0.11331 & 7.17 \\
\hline IT Resources & 0.00202 & 0.1280 \\
\hline IT Development & 0.00120 & 0.0758 \\
\hline HR Capability & 0.00092 & 0.0583 \\
\hline Knowledge & 0.00060 & 0.0379 \\
\hline IT Support & 0.00046 & 0.0292 \\
\hline Market & 0.00029 & 0.0186 \\
\hline IT Spending & 0.00029 & 0.0185 \\
\hline Innovation & 0.00027 & 0.0169 \\
\hline Labor & 0.00013 & 0.00833 \\
\hline Capital & 0.00005 & 0.00326 \\
\hline & &
\end{tabular}

\section{Comparative Analysis}

At this stage, a qualitative analysis will be carried out which aims to find out the differences between forms of research that also utilize hybrid IT value models. Comparisons are made on certain parameters as represented in Table 11.

Table 11. Comparative Analysis

\begin{tabular}{|c|c|c|c|}
\hline Parameter & Suhardi (2017) & Hizkia (2017) & This Research \\
\hline Data & $\begin{array}{l}\text { BPS City/regency of West } \\
\text { Sumatera }\end{array}$ & Bank BJB 2007-2016 & $\begin{array}{l}\text { Bank BJB } \\
2007-2016\end{array}$ \\
\hline $\begin{array}{l}\text { Examination } \\
\text { method }\end{array}$ & $\begin{array}{l}\text { Correlation, } \quad \text { Meta- } \\
\text { Analysis }\end{array}$ & $\begin{array}{l}\text { Partial Adjustment Valuation } \\
\text { (PAV) }\end{array}$ & $\begin{array}{l}\text { Bayesian } \\
\text { Network (BN) }\end{array}$ \\
\hline Data type & $\begin{array}{l}\text { Quantitative, } \\
\text { Qualitative } \\
\end{array}$ & $\begin{array}{l}\text { Quantitative, } \\
\text { Qualitative }\end{array}$ & $\begin{array}{l}\text { Quantitative, } \\
\text { Qualitative }\end{array}$ \\
\hline $\begin{array}{l}\text { Express } \\
\text { uncertainty }\end{array}$ & No & No & Yes \\
\hline Parameter & $\begin{array}{l}\text { IT resources: } \\
\text { Technology resources } \\
\text { (X1) } \\
\text { Human resources (X2) } \\
\text { Organization capability: } \\
\text { Internal capability (M1) } \\
\text { External capability (M2) } \\
\text { Organization core } \\
\text { competence: } \\
\text { Competence (M3) } \\
\text { Organization } \\
\text { performance: } \\
\text { Financial performance } \\
\text { (Y1) } \\
\text { Efficiency performance } \\
\text { (Y2) } \\
\text { Others performance (Y3) }\end{array}$ & $\begin{array}{l}\text { IT resources: } \\
\text { (i) Capital } \\
\text { (ii) Labor } \\
\text { (iii) IT spending } \\
\text { Capabilities: } \\
\text { (i) Knowledge } \\
\text { (ii) HR } \\
\text { (iii) IT Dev } \\
\text { Core competence: } \\
\text { (i) Market } \\
\text { (ii) Innovation } \\
\text { (iii) IT support } \\
\text { Firm Performance (Income) }\end{array}$ & $\begin{array}{l}\text { IT resources: } \\
\text { (i) Capital } \\
\text { (ii) Labor } \\
\text { (iii) IT } \\
\text { spending } \\
\text { Capabilities: } \\
\text { (i) Knowledge } \\
\text { (ii) HR } \\
\text { (iii) IT Dev } \\
\text { Core } \\
\text { competence: } \\
\text { (i) Market } \\
\text { (ii) Innovation } \\
\text { (iii) IT } \\
\text { support }\end{array}$ \\
\hline
\end{tabular}


I Gusti Bagus Baskara Nugraha, et al.

\begin{tabular}{|c|c|c|c|}
\hline Parameter & Suhardi (2017) & Hizkia (2017) & This Research \\
\hline & & & $\begin{array}{l}\text { Firm } \\
\text { Performance } \\
\text { (Income) }\end{array}$ \\
\hline $\begin{array}{l}\text { Calculation } \\
\text { of dependent } \\
\text { variable }\end{array}$ & No & Yes & Yes \\
\hline Model output & $\begin{array}{l}\text { Knowing the relationship } \\
\text { between variables } \\
\text { (low/medium/high } \\
\text { relationship), the effect } \\
\text { between the variables } \\
\text { (positive, negative) and } \\
\text { the direction of the } \\
\text { relationships } \\
\text { IT value hybrid model } \\
\text { complete with the } \\
\text { components interaction }\end{array}$ & $\begin{array}{l}\text { The interaction/relationship, } \\
\text { the estimation value of each } \\
\text { variables, speed of adjustment, } \\
\text { performance values, } \\
\text { performance ratio } \\
\text { IT value analysis might } \\
\text { depends on the performance } \\
\text { value and performance ratio of } \\
\text { IT model compared to the non } \\
\text { IT model }\end{array}$ & $\begin{array}{l}\text { Inference and } \\
\text { diagnosis } \\
\text { probability } \\
\text { values }\end{array}$ \\
\hline
\end{tabular}

Table 11 shows that this research has contribution in considering uncertainty into variable calculation. Uncertainty is represented as a probability value that depends on the outcome of an event. The dependent variable at $\mathrm{BN}$ is calculated to determine the joint probability distribution value.

\section{Conclusion}

We have proposed a probabilistic inference model on hybrid IT value model using Bayesian Network. The probability graphical model and equations have been presented. The model shows that inference and diagnosis can be analyzed by giving evidence to the node so that possible conditions can be predicted for various scenarios. The remaining problem is adding decision nodes to calculate the probability of taking a possible decision.

\section{References}

[1]. B. L. Martin, Idea with Impact Harvard Business Review on The Business Value of IT. Boston, Massachusetts: Harvard Business School Publishing, 1999.

[2]. L. Abdurrahman, Suhardi, and A.Z.R. Langi, "Modeling Information Technology Value," First Int. Semin. Conf. Learn. Organ., pp. 507-515, 2013.

[3]. S.K. Frank, "Expert-based Bayesian Network Modeling for Environmental Management," A Doctoral Thesis, Institute of Physical Geography of Frankfurt University, 2015.

[4]. G. P. Schell, "IT Value: From Moore's Law to a Flat World," Computer, vol. 43, no. 9, pp. 79-81, 2010.

[5]. Suhardi, N. B. Kurniawan, A. Subrata, and J. Sembiring, "Modeling IT Value based on Meta-Analysis," Electr. Eng. Comput. Sci. Informatics (EECSI), 2017 th Int. Conf., no. September, pp. 19-21, 2017.

[6]. T. Liang, J. You, and C. Liu, "A resource-based perspective on information technology and firm performance: a meta analysis," Ind. Manag. Data Syst., vol. 110, no. 8, pp. 11381158, 2010.

[7]. L. Abdurrahman, A. Z. R. Langi, and T. M. Simatupang, "Information Technology Value Engineering Model and Cost Efficiency in IT-Based Firms," IEEE Systems Journal, vol. 12, no. 3, pp. 2925-2936, 2017.

[8]. N. Nicolian, et al., "Critical Organizational Challenges in Delivering Business Value from IT: In Search of Hybrid IT Value Models," The Electronic Journal Information Systems Evaluation, vol. 18, no. 2, pp. 129-145, 2015. 
[9]. L. Abdurrahman, "Hybrid Configuration in Information Technology Value Model," IEEE Systems Journal, 2020.

[10]. W.T. Lin, C.H. Chuang, and J.H. Choi, "A partial adjustment approach to evaluating and measuring the business value of information technology," International Journal of Production Economics, vol. 127, no. 1, pp.158-172, 2010.

[11]. W. T. Lin and T. W. Kao, "The partial adjustment valuation approach with dynamic and variable speeds of adjustment to evaluating and measuring the business value of information technology," Eur. J. Oper. Res., vol. 238, no. 1, pp. 208-220, 2014.

[12]. R. F. Hizkia, N. B. Kurniawan, and Suhardi, "Hybrid IT Value Model Validation for Banking Sector using Partial Adjustment Valuation," Proceeding 2017 Int. Conf. Inf. Technol. Syst. Innov., 2017.

[13]. L. Abdurrahman, Suhardi, A.Z.R. Langi, "Valuation Methodology of Information Technology (IT) Value in the IT-based Business A Case Study at a Leading Telecommunication Company," International Journal on Electrical Engineering and Informatics, vol. 8, no. 4, pp. 865-885, 2016.

[14]. D. Koller and N. Friedman, Probabilistic Graphical Models: Principles and Techniques. The MIT Press, 2009.

[15]. O. Pourret, P. Naïm, and B. Marcot, Bayesian Networks: A Practical Guide to Applications, Wiley, 2008.

[16]. J. Sembiring, et al., "Network Security Risk Analysis using Improved MulVAL Bayesian Attack Graphs," International Journal on Electrical Engineering and Informatics, vol. 7, no. 4, pp. 735-753, 2015.

[17]. B. Drury, et al., "A Survey of the Applications of Bayesian Networks in Agriculture," Engineering Applications of Artificial Intelligence, vol. 65, pp. 29-42, 2017.

[18]. M.E. Kragt, A Beginner Guide to Bayesian Network Modelling for Integrated Catchment Management, Landscape Logic, 2009.

[19]. P.A. Leicester, "The Development of Object Oriented Bayesian Networks to Evaluate The Social, Economic and Environmental Impacts of Solar PV," A Doctoral Thesis, Loughborough University, 2015.

[20]. K.B. Korb and A.E. Nicholson, Bayesian Artificial Intelligence, $2^{\text {nd }}$ Edition, CRC Press, 2010.

[21]. C.A. Pollino and C. Henderson, "Bayesian Networks: A Guide for Their Application in Natural Resource Management and Policy," Landscape Logic Technical Report No. 14, 2010.

[22]. S. Gupta and H. W. Kim, "Linking structural equation modeling to Bayesian networks: Decision support for customer retention in virtual communities," Eur. J. Oper. Res., vol. 190, no. 3, pp. 818-833, 2008.

[23]. Netica [Online]. Available: https://norsys.com/download.html, Accessed on: May 31, 2020.

[24]. A.F. Villaverde, et al., "MIDER: Network Inference with Mutual Information Distance and Entropy Reduction," PLoS ONE, vol. 9, no. 5, 2014. 


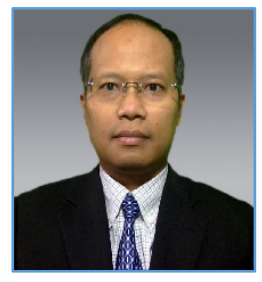

I Gusti Bagus Baskara Nugraha received the B.Eng. and M.Eng. degrees in electrical engineering from Institut Teknologi Bandung, Indonesia, in 1999 and 2001, respectively. He received the $\mathrm{PhD}$ degree from the University of Electro-Communications, Tokyo, Japan in 2006. He is currently with the School of Electrical Engineering and Informatics, Institut Teknologi Bandung, Indonesia. His research interests are in information systems and networks.

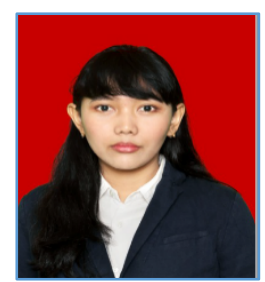

Imaniar Ramadhani received the B.Eng in informatic Engineering from Telkom University, Bandung, Indonesia, in 2014. She received Master of Engineering degree from Institut Teknologi Bandung, Indonesia, in 2018. She is currently working for PT. Bank Rakyat Indonesia (Persero), Tbk. of Indonesia.

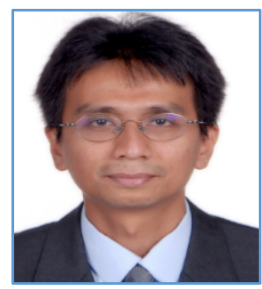

Jaka Sembiring received the B.Eng degree in Electrical Engineering from Institut Teknologi Bandung, Indonesia in 1990. He received the M.Eng. and Doctor of Engineering degrees both in Electrical Engineering from Waseda University, Japan in 1997 and 2000, respectively. Currently he is a Professor in Information Science at the School of Electrical Engineering and Informatics, Institut Teknologi Bandung. His research interests are in the field of information science, probability and stochastic systems. 